\title{
DETERMINATION OF PHYSICOCHEMICAL PROPERTIES, ANTIOXIDANT CONSTITUENTS BY HIGH-PERFORMANCE THIN-LAYER CHROMATOGRAPHY FINGERPRINTING, AND ANTIOXIDANT ACTIVITY OF CUCURBITA MAXIMA SEEDS
}

\author{
PINKI PAL, SHIV BHADRA SINGH, AADITYA SINGH \\ Department of Pharmacy, Faculty of Pharmaceutical Sciences Aryakul Group of Colleges, Lucknow, Uttar Pradesh, India. \\ Email: shiv.1013@gmail.com
}

Received: 08 November 2017, Revised and Accepted: 08 December 2017

\begin{abstract}
Objective: The present study is designed to evaluate preliminary phytochemical constituents, physiochemical properties evaluation, free radical scavenging activity, and high-performance thin-layer chromatography (HPTLC) fingerprinting analysis of Cucurbita maxima seed oil.

Methods: Total phenol content, total flavonoid content, total tannin content, 1, 1-diphenyl, 2-picryl-hydrazyl (DPPH) radical scavenging method, and HPTLC fingerprinting analysis for compounds responsible for antioxidant activity were used.

Result: Phytochemical screening shows the presence of constituents such as alkaloids, glycosides, carbohydrates, fixed oil and fats, phytosterols, saponin, phenolic compounds, tannins, proteins, amino acids, gums, and mucilage. Physicochemical studies show that the oil contains an acid value, saponification value, iodine value of $9.53 \mathrm{mg} \mathrm{KOH} / \mathrm{g}, 183 \mathrm{mg} \mathrm{KOH} / \mathrm{g}$, and $116.51 \mathrm{mg} \mathrm{I} / 100 \mathrm{~g}$, respectively. Total phenol content was $3.9498 \pm 3.2 \mathrm{mg}$ gallic acid equivalent/g, total flavonoid content was $56.115 \pm 4.6 \mathrm{mg}$ rutin equivalent/g, and total tannin content was $19.4 \pm 0.40 \mathrm{mg}$ tannic acid equivalent/g. The radical scavenging activity by DPPH Model shows that the methanolic extract has maximum antioxidant activity with IC ${ }_{50}$ value of 238.31. HPTLC fingerprinting also proofs the presence of phenol and flavonoid compounds in the seed oil.
\end{abstract}

Conclusion: The results in the paper show that the C. maxima seed oil is an natural antioxidant and can be used for the treatment of various disorders.

Keywords: Pumpkin, Antiradical scavenging, Carotenoids, Phytochemical studies.

(C) 2018 The Authors. Published by Innovare Academic Sciences Pvt Ltd. This is an open access article under the CC BY license (http://creativecommons. org/licenses/by/4. 0/) DOI: http://dx.doi.org/10.22159/ajpcr.2018.v11i3.23552

\section{INTRODUCTION}

The use of food and food products as medicine has been in practice over centuries, and the extracts from the family Cucurbitaceae have been used in the preparation of medicines for a variety of diseases in Ayurveda and ancient Chinese medicine [1]. Cucurbitaceae, commonly known as gourd family, is a family of about 120 genera and more than 800 species, the family is distributed mainly in tropical and subtropical regions of the world. Some of its largely represented genera include Benincasa, Cucurbita, Cucumis, Lagenaria, Momordica, Luffa, and Trichosanthes [2].

Cucurbitaceae is divided into two subfamilies, which are well characterize: Zanonioideae and Cucurbitoideae. The subfamily Cucurbitoideae contains the food producing plants. Varieties of both pumpkin and squash fall under the species Cucurbita pepo, Cucurbita maxima, Cucurbita moschata, and Cucurbita mixta.

Pumpkin plant has large leaves, sprawling veins with coiled, modified leaves called tendrils. The leaves are simple, alternate, and shallowly to deeply lobed. The root near the surface stem would be square, flowers will be bright yellow, and the fruit is more fibrous and less sweet than winter squash. Seed varies in size depending on variety and type. Pumpkin seed has a natural protective skin called the hull. The pumpkin plant has been grown since the earliest history of humankind. The annual species is probably native to Asia but now neutraliszed to temperate and warmer areas [3].

C. maxima also known as pumpkin, gourd, acorn squash, marrow, and summer squash and locally known as kaddu, konda, and kumra. It is grown for its fruit and edible seeds. It has white seeds enclosed in a husk. These seeds are chewable and sweet with a little nutty flavor [3,4]. The pumpkin seeds yield approximately $50 \%$ oil, (mostly linoleic and oleic acid), but the main active constituents are $\Delta 7$ sterols (avenasterol and spinasterol) and $\Delta 5$ sterol (sitosterol and stigmasterol). It also contains triterpenoids, sesquiterpenoids, squalene, tocopherols ( $\alpha$-tocopherol is predominant), carotenoids, minerals (particularly, phosphorus, potassium, magnesium, calcium, iron, zinc, and trace elements), proteins and amino acids, carbohydrates (6-10\%), vitamins (thiamine, riboflavin, niacin, pyridoxine, and pantothenic acid), phenolic glycosides, and lignans. C. maxima has been traditionally used as diuretic and anthelmintic. The seeds and oil from pumpkin seeds have been used for many years for the relief of difficulties associated with an enlarged prostate gland and micturition problems related to irritable bladder.

The fruit is cooling and astringent to the bowels, increases appetite, cures leprosy, and purifies the blood. Seeds cure sore chests, hemoptysis, bronchitis, and fever. The seed extracts of C. maxima modulate immunobiochemical pathways induced by interferons [4]. Seeds are useful in the management of benign prostatic hyperplasia. ${ }^{5}$ seed extract has antioxidant capacity [6].

\section{METHODS}

Chemicals

All the chemical used like such as $\mathrm{KOH}$, pPhenolphthalein indicator, $\mathrm{HCl}$, carbon tetrachloride, Wijs reagent, potassium iodide, sodium thiosulfate, starch, Folin-Ciocalteus reagent, gallic acid, tannic acid, rutin, and 1, 1-diphenyl, 2-picryl-hydrazyl (DPPH) etc . were of analytical grade and purchased commercially from S D Fine, Mumbai. 
Table 1: Preliminary phytochemical screening of seed extracts of Cucurbita maxima

\begin{tabular}{|c|c|c|c|c|c|}
\hline Plant constituents test/reagent used & Hexane & Chloroform & Methanol & Ethanol & Water \\
\hline $\begin{array}{l}\text { Alkaloids } \\
\text { Meyer's reagent } \\
\text { Dragendorff's reagent }\end{array}$ & + & + & - & + & + \\
\hline $\begin{array}{l}\text { Carbohydrate and glycosides } \\
\text { Fehling solution }\end{array}$ & - & - & + & + & + \\
\hline Molisch solution & - & + & - & - & + \\
\hline Benedict reagent & - & + & - & - & - \\
\hline Phytosterols & + & - & - & - & + \\
\hline Libermann's test & - & - & + & - & + \\
\hline Lieberman & - & - & - & - & - \\
\hline Burchard's test & + & + & + & - & - \\
\hline $\begin{array}{l}\text { Fixed oil and fats } \\
\text { Spot test } \\
\text { Saponification test }\end{array}$ & + & + & + & - & + \\
\hline $\begin{array}{l}\text { Saponin } \\
\text { Foam test } \\
\text { Hemolysis test }\end{array}$ & - & - & - & + & + \\
\hline $\begin{array}{l}\text { Phenolic compound and tannin } \\
\text { Ferric chloride solution } \\
\text { Gelatin solution } \\
\text { Lead acetate solution } \\
\text { Aqueous bromine solution }\end{array}$ & + & + & + & + & + \\
\hline $\begin{array}{l}\text { Protein and amino acid } \\
\text { Millon's reagent } \\
\text { Biuret test } \\
\text { Ninhydrin reagent }\end{array}$ & - & - & + & + & + \\
\hline $\begin{array}{l}\text { 8-Gum and mucilage } \\
\text { Alcoholic test } \\
\text { Precipitation test } \\
\text { Molisch test }\end{array}$ & - & - & - & + & + \\
\hline
\end{tabular}

Table 2: Physicochemical properties of seed oil of Cucurbita maxima

\begin{tabular}{llll}
\hline S. No. & Oil property & Unit & Value \\
\hline 1. & State of oil & - & Liquid \\
2. & Color of oil & - & Yellowish \\
3. & Oil content & $\%$ & 28.1 \\
4. & Acid value & $\mathrm{Mg} \mathrm{KOH} / \mathrm{g}$ & 9.53 \\
5. & Saponification value & $\mathrm{mg} \mathrm{KOH} / \mathrm{g}$ & 183 \\
6. & Iodine value & $\mathrm{mg} \mathrm{I}^{2} / 100 \mathrm{~g}$ & 116.51 \\
\hline
\end{tabular}

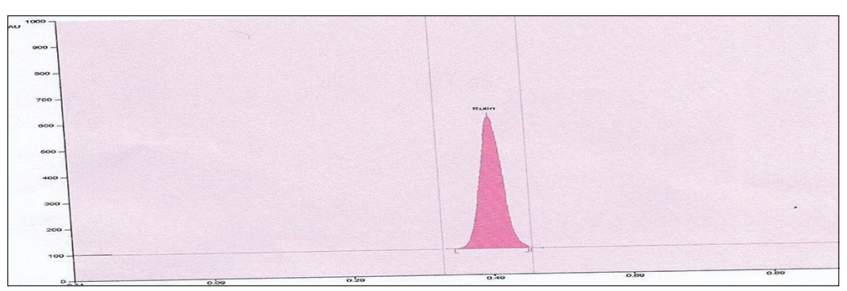

Fig. 1: High-performance thin-layer chromatography densitogram - Standard

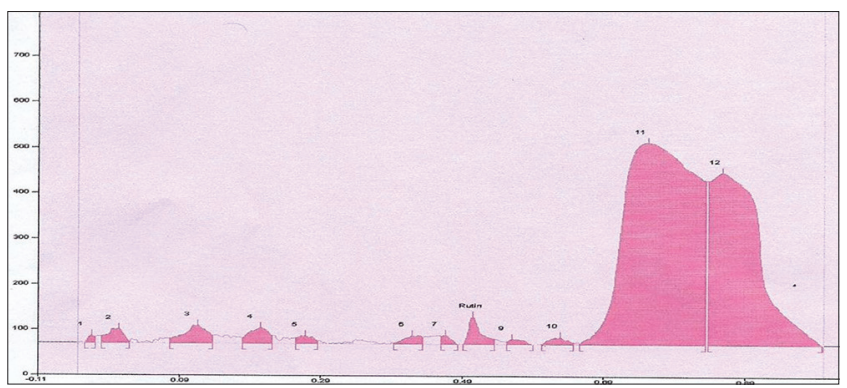

Fig. 2: High-performance thin-layer chromatography densitogram - Sample extract

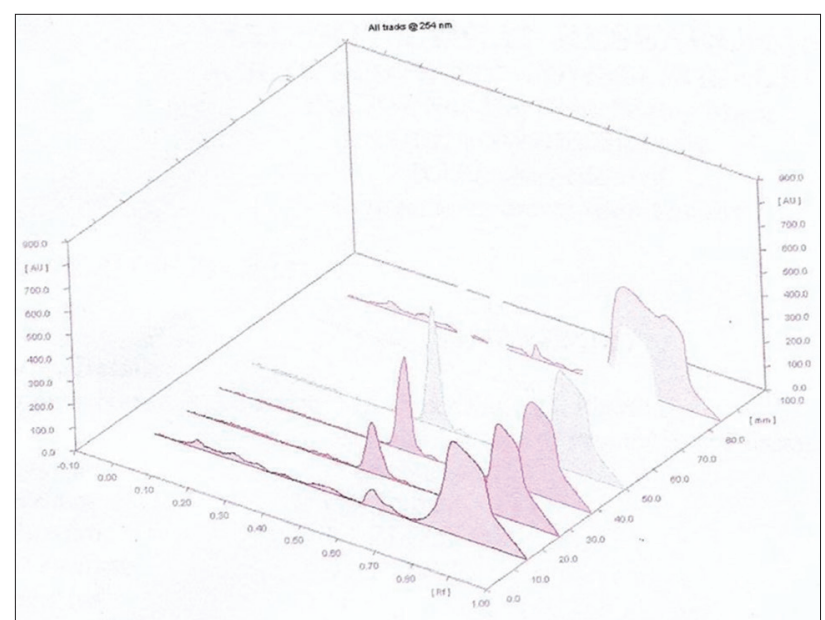

Fig. 3: High-performance thin-layer chromatography (HPTLC) densitogram - 3D diagram of HPTLC densitograms

Plant material

The dried seeds of $C$. maxima were purchased from local market of Lucknow, Uttar Pradesh, India. The purchased seeds are authenticated by a taxonomist from CSIR- NBRI Lab, Lucknow. A voucher specimen no (NBRI/CIF/531/2016) has been submitted.

\section{Preparation of extract}

The purchased seed material from market is screened for any impurities and dried. Dried seeds were grind to coarse powder using a electric grinder, sheaved ( 80 mesh), and stored in airtight jars until use. The dried powder seeds were extracted by Soxhlet apparatus using hexane, chloroform, methanol, ethanol, and water successively. Each time before employing the solvent of higher polarity marc was dried. Each extract was then concentrated using rotary vacuum evaporator at 
Table 3: Total phenolics, flavonoids, and tannins content of extracts of Cucurbita maxima

\begin{tabular}{llll}
\hline Plant extracts & $\begin{array}{l}\text { Total phenolics } \\
\text { (mg gallic acid equivalent/g)* }\end{array}$ & $\begin{array}{l}\text { Total flavonoid } \\
\text { (mg rutin equivalent/g)* }\end{array}$ & $\begin{array}{l}\text { Total tannin } \\
\text { (mg tannic acid equivalent/g)* }\end{array}$ \\
\hline Methanolic extract & $3.9498 \pm 3.2$ & $56.115 \pm 4.6$ & $19.4 \pm 0.40$ \\
\hline${ }^{*} \mathrm{n}=3$ & & &
\end{tabular}

Table 4: Results of DPPH radical scavenging activity

\begin{tabular}{|c|c|c|c|c|c|c|}
\hline \multirow[t]{2}{*}{ S. No. } & \multirow[t]{2}{*}{ Extract } & \multicolumn{5}{|c|}{ Concentration $(\mu \mathrm{g} / \mathrm{ml})$ and $\%$ inhibition } \\
\hline & & 20 & 40 & 60 & 80 & 100 \\
\hline 1 & Standard gallic acid & 91.1 & 91.4 & 92.4 & 92.9 & 93.6 \\
\hline 2 & Hexane & 20.3 & 20.9 & 25.2 & 29.0 & 30.9 \\
\hline 3 & Chloroform & 18.8 & 19.2 & 20.8 & 21.2 & 22.3 \\
\hline 4 & Methanol & 42.6 & 45.7 & 48.9 & 55.2 & 59.3 \\
\hline 5 & Ethanol & 30.0 & 32.8 & 35.3 & 38.6 & 39.3 \\
\hline 6 & Water & 30.2 & 33.7 & 39.4 & 40.1 & 42.5 \\
\hline
\end{tabular}

Table 5: $\mathrm{IC}_{50}$ value for DPPH radical scavenging assay

\begin{tabular}{lll}
\hline S.No. & Plant extract & IC $_{\mathbf{5 0}}{\text { value }(\boldsymbol{\mu g} / \mathbf{m l})^{*}}$ \\
\hline 1 & Hexane & 150.43 \\
2 & Chloroform & 120.13 \\
3 & Methanol & 238.31 \\
4 & Ethanol & 181.31 \\
5 & Water & 125.93 \\
\hline
\end{tabular}

Table 6: HPTLC - fingerprinting extract (mobile phase - ethyl acetate: butanone: formic acid: water - 5:3:1:1)

\begin{tabular}{lllll}
\hline Peak & Rf value & Start height (AU) & End height (AU) & Area (AU) \\
\hline 1 & 0.04 & 0.3 & 14.7 & 167.2 \\
2 & 0.00 & 15.9 & 3.3 & 781.5 \\
3 & 0.11 & 10.5 & 18.3 & 1345.5 \\
4 & 0.20 & 12.5 & 17.8 & 1007.5 \\
5 & 0.27 & 36.6 & 7.0 & 406.1 \\
6 & 0.42 & 28 & 16.3 & 491.2 \\
7 & 0.46 & 18.6 & 0.3 & 267.5 \\
8 & 0.50 & 0.8 & 12.0 & Unknown \\
9 & 0.56 & 6.8 & 0.2 & Unknown \\
10 & 0.63 & 1.8 & 4.3 & Unknown \\
11 & 0.75 & 3.9 & 58.3 & Unknown \\
12 & 0.86 & 358.3 & 1.2 & Unknown \\
\hline
\end{tabular}

HPTLC: High-performance thin-layer chromatography

$40-50^{\circ} \mathrm{C}$ under vacuum, and dried residue was collected and stored in the refrigerator for further experimentation.

Phytochemical screening

Phytochemical screening is done according to method of C. K. Kokate, Practical Pharmacognosy, for hexane, chloroform, ethanol, methanol, and water extract [7] and results were tabulated in Table 1.

\section{Physiochemical studies}

The physiochemical parameters in hexane extract were determined using methods reported in AOAC 1990 [8], and results were tabulated in Table 2.

\section{In vitro antioxidant activity}

Estimation of total phenolic content, estimation of total flavonoid content [9], and estimation of tannin content, were expressed in terms of mg gallic acid equivalent/g, mg rutin equivalent/g, and $\mathrm{mg}$ tannic acid equivalent/g based on the calibration curves of standards, i.e. gallic acid, rutin, and tannic acid, respectively. The radical scavenging potential was analyzed through DPPH radical scavenging assay [10].

\section{DPPH antiradical activity}

DPPH method is performed using Gallic acid as standard. Extracts of all solvents are dissolved in methanol to achieve a concentration of 20,40, 60,80 , and $100 \mu \mathrm{g} / \mathrm{mL}$ and were mixed with $400 \mu \mathrm{M}$ DPPH methanol solution at a ratio 1:3. A control was prepared using methanol and DPPH solution. The mixture was mixed well and set in the dark at room temperature for $40 \mathrm{~min}$. The change of color from violet to yellow of DPPH was determined by measuring the absorbaence at $517 \mathrm{~nm}$. The percentage of inhibition was calculated by the given formula and also $\mathrm{IC}_{50}$ Value is calculated.

(\%) Scavenging activity=Control absorbance-Test absorbance $\times 100 /$ Control absorbance

\section{Chromatographic estimation}

Development of high-performance thin-layer chromatography (HPTLC) method for analysis of phenols and flavonoids

HPTLC analysis was carried out using Camag HPTLC system equipped with Linomat-V applicator and $100 \mu \mathrm{l}$ syringe. The samples were spotted in the form of bands using microliter syringe on pre-coated silica gel 60 
$\mathrm{F}_{254}$ HPTLC plates, and development of the applied plate was carried out in pre-saturated Camag twin-trough chamber. The mobile phase used was ethyl acetate: Butanone: Formic acid: Water in a ratio of 5:3:1:1. The developed plates were dried and analyzed at $254 \mathrm{~nm}$ and $366 \mathrm{~nm}$, and the results are interrelated in Tables 3-6 and Figs.1-3.

\section{RESULTS}

\section{DISCUSSION}

As per Table 1, various important phytochemicals such as alkaloids, glycosides, carbohydrates, fixed oil and fats, phytosterols, saponin, phenolic compounds, tannins, proteins, amino acids, gums, and mucilage are present in hexanoic, chloroform, methanolic, ethanolicm and water extracts of $C$. maxima which are very valuable for various therapeutic activities.

As per Table 2, the acid value was $9.53 \mathrm{mg} \mathrm{KOH} / \mathrm{g}$, this indicates that oil of $C$. maxima is safer for human consumption and also does not undergo deterioration. Saponification value was $183 \mathrm{mg} \mathrm{KOH} / \mathrm{g}$ which shows that the oil is suitable for biodiesel processing. Iodine value was $116.51 \mathrm{mg} \mathrm{I} / 100 \mathrm{~g}$ which indicates that it is more suitable for biodiesel production and is a drying oil.

Antioxidant potential of many plants is due to total phenolic components which includes phenolic acid and phenolic diterpenes. As per Table 3, total phenol content was $3.9498 \pm 3.2 \mathrm{mg}$ gallic acid equivalent/g, total flavonoid content was $56.115 \pm 4.6 \mathrm{mg}$ rutin equivalent $/ \mathrm{g}$, and total tannin content was $19.4 \pm 0.40 \mathrm{mg}$ tannic acid equivalent/g which shows that the plant has antioxidant properties.

Table 4 shows \% inhibition by radical scavenging methods and Table 5 shows $\mathrm{IC}_{50}$ value for DPPH radical scavenging assay which shows that the methanolic extract has maximum antioxidant activity and hence contains maximum antioxidant components.

Table 6 shows that the HPTLC fingerprinting of methanolic extract in mobile phase was ethyl acetate: butanone: Formic acid: Water in a ratio of 5:3:1:1 and densitogram shows the presence of rutin at $\mathrm{R}_{\mathrm{f}}$ value of 0.5 .

\section{CONCLUSION}

C. maxima belonging to family Cucurbitaceae is a plant which is also used as food, it is very easily available and can be used for the treatment of various disorders because the results in the paper show that the C. maxima seed oil is a very good natural antioxidant.

\section{REFERENCES}

1. Palamthodi S, Lele SS. Nutraceutical applications of gourd family vegetables: Benincasa hispida, Lagenaria siceraria and Momordica charantia. Biomed Prev Nutr 2014;4:15-21.

2. Rahman AH, Anisuzzaman M, Ahmed F, Islam AK, Naderuzzaman AT. Study of nutritive value and medicinal uses of cultivated cucurbits. J Appl Sci Res 2008;4:555-8.

3. Mythili P, Kavitha T. Overview on Cucurbita maxima Seed. IOSR J Dent Med Sci 2017;16:29-33.

4. Acosta-Patiño JL, Jiménez-Balderas E, Juárez-Oropeza MA, DíazZagoya JC. Hypoglycemic action of cucurbita ficifolia on Type 2 diabetic patients with moderately high blood glucose levels. J Ethnopharmacol 2001;77:99-101.

5. Winkler C, Wirleitner B, Schroecksnadel K, Schennach H, Fuchs D. Extracts of pumpkin (Cucurbita pepo L.) seeds suppress stimulated peripheral blood mononuclear cells in vitro. Am J Immunol 2005;1:6-11.

6. Abdel-Rahman MK. Effect of pumpkin seed (Cucurbita pepo L.) diets on benign prostatic hyperplasia (BPH): Chemical and morphometric evaluation in rats. World J Chem 2006;1:33-40.

7. Kokate CK. Practical Pharmacognosy. Delhi: Vallabh Prakashan; 2008. p. 108-9.

8. AOAC. Official Methods of Analysis $.15^{\text {th }}$ ed. Washington, VA: Association of Official Analytical Chemists; 1990.

9. Ordonez AA, Gomez JD, Vattuone MA, Isla MI. Antioxidant activities of Sechium edule (Jacq.) Swart extracts. Food Chem 2006;97:452-8.

10. Nair VD, Panneerselvam R, Gopi R. Studies on methanolic extract of Rauvolfia species from Southern Western Ghats of India-in vitro antioxidant properties, characterisation of nutrients and phytochemicals. Ind Crops Prod 2012;39:17-25.

11. Charoonratana T, Settharaksa S, Madaka F, Songsak T. Screening of antioxidant activity and total phenolic content in Raphanus sativus pod. Int J Pharm Pharm Sci 2014;6:224-6.

12. Dixit A, Singh H, Sharma RA, Sharma A. Estimation of antioxidant and antibacterial activity of crude extracts of Thevetia peruviana (pers.) $\mathrm{k}$. schum. Int J Pharm Pharm Sci 2015;7:55-9. 